\title{
Zarys modelu poziomów analizy w badaniach relacji nauki i religii
}

\section{Wstęp}

Mówiąc o relacji między nauką a religią, mam na myśli relację między twierdzeniami na temat świata, jakie spotykamy w religiach teistycznych (szczególnie w teizmie chrześcijańskim) oraz w naukach empirycznych (w szczególności w naukach przyrodniczych). Nie rozważam natomiast relacji między nauką a religią w ich aspektach instytucjonalnych, społecznych czy psychologicznych.

W artykule interesuje mnie, w jaki sposób na spotykane w literaturze ustalenia dotyczące relacji między twierdzeniami nauki i religii na temat świata wpływa nieuwzględnianie poziomów analizy podejmowanych zagadnień w argumentacji na rzecz stanowisk o zgodności lub niezgodności między nauką a religią. Przedstawię tu propozycję podziału twierdzeń o rzeczywistości, rozróżniając je pod względem stopnia empiryczności. Na najwyższym poziomie znalazłyby się twierdzenia metafizyczne (w neopozytywistycznym rozumieniu kategorii „metafizyki"), czyli o zupełnie nieempirycznym lub o empirycznie neutralnym charakterze, jak na przykład.: „Byt bytuje, a nicość nicościuje”, „Istnieje tylko materia”, „Wszystko jest procesem”, „Chrystus jest synem Jahwe”, „Bóg podtrzymuje wszystko $\mathrm{w}$ istnieniu" i tym podobne. Na najniższym znajdowałyby się twierdzenia o najwyższym stopniu empiryczności (z uwzględnieniem zastrzeżeń zawartych w dyskusjach metodologicznych wokół problemu empirycznej testowalności), jak na przykład: „Ziemia krąży wokół Słońca”, „Ślimak winniczek składa średnio 20-30 jaj”, „Wszechświat powstał w Wielkim Wybuchu około 
13,7 mld lat temu”, „Izraelici przeszli przez Morze Czerwone”, „Jezus chodził po wodzie" i tym podobne. Schemat zawiera też stopnie pośrednie.

Przez odwołanie do tego podziału pokażę, na czym polega „zbyt łatwe” konfliktowanie oraz „zbyt łatwe” godzenie nauki i religii. W przykładzie ilustrującym pierwszy z problemów będziemy mieli do czynienia z oceną teorii naukowej na podstawie założeń filozoficznych, które teoria ta odrzuca. Przedstawię tu niedawną krytykę uzgadniania tomizmu z ewolucjonizmem dokonaną przez Michała Chaberka. O wiele częściej spotyka się dziś i o wiele głośniejsze w tekstach przeznaczonych dla szerokiej publiczności są stanowiska „godzące” naukę i religię. Analizy Chaberka zaliczają się więc do nurtu mniejszościowego. Oprócz wskazania niezgodności między ewolucjonizmem i tomizmem na poziomie założeń filozoficznych krytyka ewolucjonizmu spotykana w publikacjach Chaberka dotyczy także zagadnień metodologicznych i empirycznych. Aspekt założeń filozoficznych wydaje się jednak najbardziej istotny dla jego tezy o konflikcie darwinizmu $\mathrm{z}$ tomizmem, stąd pominięte zostają inne wątki jego krytyki ewolucjonizmu.

Mankamentem omówionego „zbyt łatwego” sposobu godzenia nauki i religii jest zmiana znaczeń kategorii, które wcześniej występowały w twierdzeniach jednego poziomu, na znaczenia przypisywane tym kategoriom na poziomach wyższych. Problem ten zilustruję spotykanym u niektórych teistów naturalistycznych odejściem od interwencjonistycznego rozumienia koncepcji Bożego działania w świecie na rzecz jej rozumienia jako wyłącznie podtrzymywania $\mathrm{w}$ istnieniu każdego zdarzenia w świecie. Podobne przesunięcie występuje przy rozumieniu Boskiego aktu stworzenia jako ciągłego stwarzania polegającego na stałym podtrzymywaniu świata $\mathrm{w}$ istnieniu. Innymi słowy, pogodzenie nauki i religii polega tu na zmianie zawężającej znaczenie tradycyjnej koncepcji religijnej. Przedstawiony model poziomów analizy ułatwia dostrzeżenie, że istotą tej strategii jest wycofanie się z twierdzeń o charakterze empirycznym na rzecz nieempirycznych twierdzeń z metafizycznego poziomu analizy.

W ostatniej części będę argumentował, że ontologia przyrody zawarta w założeniach współczesnej nauki nie jest wcale bardziej naturalistyczna niż ontologia hylemorfizmu arystotelesowskiego w przyrodoznawstwie średniowiecznym. Różnica między średniowiecznymi a niektórymi dzisiejszymi ujęciami relacji te- 
izmu chrześcijańskiego $\mathrm{z}$ naukową wizją przyrody polega na uznaniu przez współczesnych myślicieli, godzących naukę i religię, autorytetu nauki nie tylko na poziomie twierdzeń empirycznych, ale też na ich uległości wobec naturalistycznych przesłanek z poziomów wyższych. Tym samym odejście od interwencjonistycznych i dualistycznych koncepcji relacji Boga i świata na rzecz nieinterwencjonistycznych i monistycznych prowadzi ich do przyjmowania jedynie skrajnie nieempirycznych twierdzeń na temat relacji świata i sfery nadprzyrodzonej.

\section{Problemy konfliktu oraz zgodności ewolucjonizmu z teizmem chrześcijańskim na przykładzie niektórych odwołań do tomizmu}

\section{A. „Zbyt latwe” odrzucenie teorii naukowej na podstawie argumentacji religijnej}

W swoich niedawnych publikacjach Michał Chaberek stara się wykazać, iż wbrew popularnemu dziś poglądowi, nieuzasadnione są twierdzenia, jakoby filozofia Tomasza z Akwinu była zgodna z darwinowską koncepcją rozwoju życia na Ziemi. Innymi słowy, argumentuje on, że z punktu widzenia tomizmu nie można twierdzić, że Bóg posłużył się ewolucją przy stworzeniu różnorodności gatunków. Poniżej krótko przedstawię stwierdzenia krytykowane przez Chaberka oraz jego kontrargumentację.

Krytykowane przez Chaberka stanowisko zalicza się do tzw. teistycznego ewolucjonizmu, który w tej szczególnej postaci posługuje się odwołaniami do filozofii tomistycznej. Zgodnie z charakterystyką tego stanowiska, przytoczoną przez Chaberka w artykule „Św. Tomasz z Akwinu a ewolucjonizm. Polemika z tezami Piotra Lichacza OP i Williama E. Carolla”: „[...] teistyczni ewolucjoniści twierdzą, że Bóg mógłby posłużyć się ewolucją. [...] Jednak, jak się wydaje, w swoim uzgadnianiu „nauki Tomasza” z „nauką Darwina” teistyczni ewolucjoniści idą dalej, sugerując, że nauka Tomasza nie tylko nie jest sprzeczna ze współczesną teorią ewolucji biologicznej, ale nawet w jakiś sposób ją popiera. Sugerują więc, że według św. Tomasza Bóg, stwarzając świat, nie uczynił osob- 
nych natur swoim nadprzyrodzonym działaniem, lecz że posłużył się naturalnym procesem przyrodniczym określanym mianem ewolucji”. ${ }^{1}$ Ten nurt teistycznego ewolucjonizmu przyjmuje więc nie tylko, że Bóg mógł posłużyć się ewolucją, ale że z pism Tomasza z Akwinu wręcz wynika pogląd, iż stworzenie różnorodności organizmów dokonało się za sprawą procesów przyrodniczych, niewymagających specjalnych interwencji Boga. Według Chaberka wypowiedzi Tomasza wskazują, że przyjmował on, iż Bóg nie musiał posługiwać się przy stwarzaniu przyczynami wtórnymi oraz że w rzeczywistości się nimi nie posługiwał. $^{2}$

Zacznijmy od twierdzenia, że Bóg mógł posłużyć się ewolucją. W przytoczonym artykule Chaberek stwierdza: „Ponieważ podstawowym elementem teologii chrześcijańskiej jest teza, że Bóg jest wszechmogący, nie należy się spodziewać, że znajdziemy w pismach Tomasza z Akwinu twierdzenie, że Pan Bóg nie mógłby stworzyć całej różnorodności bytów biologicznych na drodze ewolucji". ${ }^{3}$ Wydaje się więc, że według Chaberka, ze względu na uznanie tezy o wszechmocy Boga, tomizm dopuszcza możliwość, aby Bóg posłużył się ewolucją.

W innym swoim artykule Chaberek stwierdza jednak, że sprawa ta nie jest wcale taka oczywista. ${ }^{4}$ Wskazuje na tradycyjną koncepcję chrześcijańską, przyjmowaną także przez Tomasza z Akwinu, według której Bóg nie może postępować wbrew zasadzie niesprzeczności. Jak stwierdza, ,[...] aby można było twierdzić — «Bóg mógł posłużyć się ewolucją» należałoby najpierw wykazać, że pojęcie ewolucji nie jest logicznie sprzeczne". ${ }^{5} \mathrm{~W}$ dalszej części artykułu Chaberek wykazuje, że ewolucjonizm jest niespójny logicznie. Jak się jednak okaże, otrzymuje on ten wynik, zakładając bardzo specyficzną odmianę ontolo-

\footnotetext{
${ }^{1}$ Michał Chaberek OP, „Św. Tomasz z Akwinu a ewolucjonizm. Polemika z tezami Piotra Lichacza OP i Williama E. Carolla", Filozoficzne Aspekty Genezy 2012, t. 9, s. 35 [33-52], http:// www.nauka-a-religia.uz.zgora.pl/index.php?action=tekst\&id=228 (23.10.2012).

${ }^{2}$ Por. Chaberek, „Św. Tomasz z Akwinu a ewolucjonizm...”, s. 35.

${ }^{3}$ Chaberek, „Św. Tomasz z Akwinu a ewolucjonizm...”, s. 35.

${ }^{4}$ Por. Michał ChabereK, „Czy Bóg mógł się posłużyć ewolucją?”, Fronda 2012, nr 63, s. 87 [83-103].

${ }^{5}$ ChabereK, „Czy Bóg mógł się posłużyć ewolucją...”, s. 88.
} 
gii przyrodniczej, mianowicie przyjmowanego w średniowieczu hylemorfizmu, której sam ewolucjonizm jednak nie przyjmuje.

Pierwszy problem, na który wskazuje Chaberek, dotyczy zagadnienia przyczynowości. Według Chaberka ewolucjonizm przyjmuje, że przyczyna niższa wytwarza wyższy skutek, albowiem uznaje na przykład, że materia nieożywiona wytworzyła życie albo że człowiek pochodzi od zwierząt niższych. ${ }^{6}$ Zdaniem Chaberka mamy tu do czynienia z naruszeniem zasad logiki: ,[...] doskonałość skutku musi się bowiem zawierać w doskonałości przyczyn. Jest to jedna z podstawowych prawd rozumowania [...]". ${ }^{7}$ Mankament tej argumentacji Chaberka polega na tym, że kategorie, takie jak „,przyczyna wyższa”, „przyczyna niższa”, „doskonałość przyczyny”, „doskonałość skutku”, są używane przez filozofię tomistyczną, a szczególnie tomistyczno-hylemorficzną koncepcję przyrody, ale nie przez ewolucjonizm. Nawet jeśli w jakimś stopniu można tłumaczyć „doskonałość” na „złożoność”, to na pewno nie można tu mówić, że pojęcia te mają to samo znaczenie. Nawet jeśli zgodzimy się, że za pomocą tomistycznie rozumianej kategorii „doskonałości” można w ramach filozofii tomizmu analizować ewolucjonizm, to trudno uznać, że mamy do czynienia z naruszeniem zasad logiki w obrębie samego ewolucjonizmu, jeśli stanowisko to „nie przystaje” do kategorii tomistycznych.

Kolejny problem związany jest z celowością ewolucji, a dokładniej relacją między narządem a funkcją. Jak pisze Chaberek, „Widzenie, słyszenie czy czucie są pewnym pomysłem i stanowią rozwiązanie problemu komunikowania się organizmu ze światem zewnętrznym. Dopiero, gdy uprzednio istnieje to rozwiązanie w postaci określonej idei (projektu, pomysłu), wtedy może powstać narząd, gdyż to narząd jest dla funkcji, a nie odwrotnie". ${ }^{8}$ Dalej pisze, że ,[...] ewolucja nie może wytworzyć ani oka, ani ucha, ani żadnego innego funkcjonalnego narządu, gdyż ich powstanie domaga się działania analogicznego do działania architekta stosującego się do praw geometrii i techniki, aby rozwiązać

\footnotetext{
${ }^{6}$ Por. Chaberek, „Czy Bóg mógł się posłużyć ewolucją...”, s. 88.

${ }^{7}$ Chaberek, „Czy Bóg mógł się posłużyć ewolucją...”, s. 89.

${ }^{8}$ ChabereK, „Czy Bóg mógł się posłużyć ewolucją...”, s. 90.
} 
określone problemy budowlane". ${ }^{9}$ Chaberek dokonuje tu abstrahowania funkcji i narządu, co prowadzi go do swoistego dualizmu, w którym słuch może istnieć bez ucha, chód bez chodzenia, malowanie bez malarza. Dualizm ten może wydać się wynikiem po prostu hipostazowania kategorii językowych. Jednak właśnie w tomistyczno-hylemorficznej ontologii przyrody, gdzie przyjmuje się podobny dualizm formy i materii, jest też miejsce na dualizm organu i funkcji. Geneza funkcji narządu wiązałaby się tu z pomysłem, ideą, projektem w umyśle Boga.

Chaberek krytykuje tu ewolucjonizm w miejscu, w którym wielu naukowców i filozofów nauki dostrzega największą zaletę teorii Darwina. Ma nią być umożliwienie zastąpienia teleologicznych wyjaśnień pochodzenia dostosowań organizmów do warunków życia przez wyjaśnienia funkcjonalistyczne. Tę wartość darwinizmu podkreślał Karl R. Popper, gdy pisał, że choć darwinizm jest teorią metafizyczną, ${ }^{10}$ to jej wartość polega na wykazaniu właśnie, , „[...] że jest w zasadzie możliwa redukcja teleologii do przyczynowości poprzez wyjaśnienie $\mathrm{w}$ terminach czysto fizycznych istnienia projektu i celu w świecie". ${ }^{11} \mathrm{~W}$ klasycznej pracy dotyczącej wyjaśniania naukowego Wesley C. Salmon podkreślał, że właśnie od czasu Darwina „,...] właściwe jest przy wyjaśnianiu funkcjonalnym odrzucanie odwołań do celowego działania stwórcy czy jakiegokolwiek rodzaju przyczyny celowej”. ${ }^{12}$

Oczywiście istnieją ontologie przyrody niezgodne $\mathrm{z}$ darwinizmem, ale ta niezgodność nie oznacza jeszcze, że sam darwinizm jest wewnętrznie sprzeczny. Problem relacji funkcji i organu tak, jak przedstawia go Chaberek, ma miej-

${ }^{9}$ Chaberek, „Czy Bóg mógł się posłużyć ewolucją...”, s. 90-91.

${ }^{10}$ „Mimo to teoria ta jest bezcenna. [...] Jakkolwiek teoria ta jest metafizyczna, rzuca sporo światła na bardzo konkretne i bardzo praktyczne badania. Pozwala nam racjonalnie badać przystosowanie do nowego środowiska [...]: sugeruje istnienie mechanizmu adaptacji i pozwala nam nawet badać szczegóły tego mechanizmu podczas jego funkcjonowania. Jest to jedyna — jak do tej pory - teoria, która na to pozwala” (Karl R. PoPPER, Nieustanne poszukiwania: autobiografia intelektualna, przeł. Adam Chmielewski, Znak, Kraków 1997, s. 240).

${ }^{11}$ Karl R. Popper, Wiedza obiektywna. Ewolucyjna teoria epistemologiczna, przeł. Adam Chmielewski, PWN, Warszawa 1992, s. 339.

${ }^{12}$ Wesley C. Salmon, Four Decades of Scientific Explanation, University of Minnesota Press, Minneapolis 1989, s. 31-32. 
sce przy założeniu ontologii szczególnego języka, który jest bliski językowi potocznemu, ale nie jest językiem ewolucjonizmu, więc na podstawie tych analiz nie można mówić o wewnętrznej sprzeczności tej teorii.

Trzeci problem dotyczy logicznej niespójności koncepcji transformizmu gatunkowego. Jak pisze Chaberek: „Chodzi tu oczywiście o zupełnie różne natury, a nie drobne adaptacje wynikające na przykład ze zmiany środowiska, w którym dany organizm egzystuje. W klasycznej filozofii mówi się, że każdy byt ma istotę, czyli to, czym jest oraz przypadłości, czyli to, co posiada - jakieś cechy. Przypadłości nie zmieniają jednak jego istoty. [...] Teoria ewolucji głosi, że organizm określonego gatunku, na przykład ryba, pod wpływem drobnych zmian organicznych, czyli zmian przypadłościowych, takich jak zmiana koloru czy grubości łusek, może zmienić naturę, czyli, na przykład, stać się płazem. [...] Teoria postulująca transformizm gatunkowy na zasadzie kumulacji drobnych zmian organicznych występuje przeciwko logice, gdyż wynikałoby stąd, że dana rzecz jest czymś, czym jednocześnie nie jest, lub, że jest jednocześnie jedną i drugą rzeczą". ${ }^{13}$ Streszczając krótko to rozumowanie, ewolucjonizm zakłada przechodzenie jednych natur w inne, a z samej definicji „natur” wynika, że są one czymś niezmiennym, zatem ewolucjonizm jest wewnętrznie sprzeczny. Problem polega jednak na tym, czy kategorie „natury”, „istoty rzeczy” albo „,formy substancjalnej" lub coś, co im odpowiada, w ogóle występuje w teorii ewolucji czy ontologii ewolucjonizmu. Nie występuje i dlatego znów nie można uznać za uprawniony wniosek, że ewolucjonizm jest pod omawianym względem wewnętrznie sprzeczny. Ani kategoria „gatunku”, ani „rodzaju” w ujęciu ewolucjonistycznym nie jest tożsama znaczeniowo z kategoriami „natury” czy „formy gatunkowej". Występuje natomiast niezgodność między przyjmowaną przez Tomasza ontologią hylemorfizmu a ewolucjonizmem, w którym mówi się o zmiennych gatunkach, a nie o niezmiennych naturach.

Zatem choć wcześniej Chaberek pisał po prostu o wewnętrznej niespójności ewolucjonizmu, to w istocie wykazał, że istnieje tu problem niezgodności tomistyczno-arystotelesowskiego hylemorfizmu z ontologią ewolucjonistycznej koncepcji powstawania gatunków. Sam Chaberek jednak w swoich analizach nie wspomina o hylemorfizmie, choć wyraźnie ta właśnie filozofia przyrody jest

\footnotetext{
${ }^{13}$ ChabereK, „CZy Bóg mógł się posłużyć ewolucją...”, s. 91.
} 
obecna $\mathrm{w}$ jego krytyce. Wprost stwierdza natomiast, że ewolucjonizm jest niezgodny z realizmem metafizycznym. Jak pisze, „Oczywiście wymienione trzy problemy ewolucji (przyczynowości, celowości i transformizmu gatunkowego) łączą się z realistyczną metafizyką bytu. Wynika stąd jednak ważny wniosek: Jeżeli ktoś twierdzi, że «Bóg mógł posłużyć się ewolucją», to najpierw musi pożegnać klasyczną metafizykę wraz z wszystkimi jej zasadami”. ${ }^{14}$ Zasady klasycznej metafizyki jednak niekoniecznie muszą być zakładane przez ewolucjonizm, zatem trudno uznać za zasadny wniosek Chaberka o wewnętrznej niespójności ewolucjonizmu. Jak zobaczymy w dalszej części, nietrafne jest także twierdzenie, że przyjęcie klasycznej metafizyki wyklucza pogląd, że Bóg mógł posłużyć się ewolucją.

W artykule „Czy Bóg mógł się posłużyć ewolucją?” wykazanie niespójności ewolucjonizmu należy uznać - na mocy założenia, że Bóg nie może tworzyć tego, co wewnętrznie sprzeczne - za argument na rzecz odpowiedzi, że jednak nie mógł. Tym bardziej nie mógł, że wspomniana klasyczna metafizyka bytu przyjmowana jest w rozumieniu tego, czym jest Bóg. Jak pisze Chaberek: „, $[.$. Kościół od samego początku przyjmował tę «zdrową filozofię», jako podstawę racjonalnego uzasadnienia dogmatów trynitarnych, chrystologicznych i eucharystycznych. Porzucając klasyczną metafizykę, trzeba by jednocześnie porzucić większość chrześcijańskiej tradycji teologicznej”. ${ }^{15}$ Mamy tu jednak sprzeczność między dwoma różnymi filozofiami, to jest szczególną odmianą naturalizmu ewolucjonistycznego i szczególną odmianą realizmu metafizycznego, a nie wewnętrzną niespójność ewolucjonizmu.

Powyżej mieliśmy więc przykład dyskusji z obszaru relacji nauki i religii, w której wystąpiło coś, co nazwałbym ,zbyt łatwym” odrzucaniem nauki. Polegało ono tu na argumentowaniu, że dana koncepcja naukowa jest niespójna wewnętrznie, przy czym koncepcji naukowej przypisano założenia przyjmowane w ramach stanowiska religijnego, których jednak nie przyjmowała analizowana koncepcja naukowa, a wręcz były one sprzeczne z jej założeniami. Nie stawiam zarzutu, że nie należy porównywać założeń, bo należy, ale że koncepcji nauko-

\footnotetext{
${ }^{14}$ Chaberek, „Czy Bóg mógł się posłużyć ewolucją...”, s. 91.

${ }^{15}$ Chaberek, „Czy Bóg mógł się posłużyć ewolucją...”, s. 91-92.
} 
wej przypisano twierdzenia, które ona odrzuca, i na tej podstawie próbowano wykazywać jej wewnętrzną niespójność.

\section{B. „Zbyt latwe” godzenie nauki i religii}

W dalszej części zajmę się przykładem „zbyt łatwego” godzenia nauki i religii. Tu także posłużę się przykładami zastosowania elementów filozofii tomistycznej, choć obecnych także w ujęciach nietomistycznych. Jedna z głównych tez teistycznych naturalistów czy teistów naturalistycznych głosi, że należy odrzucić koncepcję interwencjonistycznego działania Boga w przyrodzie. Przez działanie interwencjonistyczne rozumie się tu wykrywalne empirycznie działanie sfery nadnaturalnej w przyrodzie, które łamałoby czy wykraczało poza naturalny porządek. Zgodnie $\mathrm{z}$ charakterystyką teizmu naturalistycznego podaną przez Van Tilla: „W przeciwieństwie do różnych form teizmu nadnaturalistycznego, teizm naturalistyczny odrzuca wymuszające nadnaturalne interwencje jako coś, co naruszałoby istotę natury Boga, świata i relacji Boga i świata". ${ }^{16}$

Koncepcja ta wyrażana jest też przez tezę, że wyjaśnienie żadnego szczegółowego zdarzenia w świecie nie wymaga odwołania do specjalnego działania Boga. Odwołania do Boga uznaje się za uzasadnione jedynie w sprawach, których sama nauka, jak się przyjmuje, nie jest kompetentna rozstrzygać, jak kwestie przyczyny samego istnienia świata, racjonalności czy inteligibilności przyrody, zbieżności tej racjonalności świata i racjonalności człowieka czy zagadnienia związane z wartościami. ${ }^{17}$ Uznaje się natomiast, że wyjaśnienie wszystkich szczegółowych własności i zdarzeń w świecie przyrody należy do kompe-

\footnotetext{
${ }^{16}$ Howard VAN TILL, „Are Bacterial Flagella Intelligently Designed? Reflection on the Rhetoric of the Modern ID Movement", Science and Christian Belief 2003, vol. 15, no. 2, s. 121 [117-140].

17 „Głębia poznawalności wszechświata (faktu, dzięki któremu możliwa jest nauka) oraz rozumne piękno ładu odkrywanego przez fizykę [...] są zbyt wymownymi cechami świata, aby traktować je jako szczęśliwy zbieg okoliczności. Sama nauka jest zbyt ograniczona w swej zdolności wyjaśniania, żeby umożliwić nam zrozumienie tego rodzaju doświadczeń. [...] Nowa teologia naturalna stara się głębiej wniknąć w ich istotę, twierdząc, że poznawalność i rozumne piękno wszechświata są śladami pozostawionymi przez rozum jego Stwórcy" (John C. Polkinghorne, Nauka i stworzenie. Poszukiwanie zrozumienia, przeł. Marek Chojnacki, Wydawnictwo WAM, Kraków 2008, s. 8).
} 
tencji nauki i że są one (lub zostaną w przyszłości) adekwatnie wyjaśniane przez naukę za pomocą odwołań do przyczyn naturalnych.

Przyjmuje się więc istnienie pewnego rodzaju luk w naukowym opisie tych szczegółowych zdarzeń i własności. Określa się je mianem „luk eksplanacyjnych”. Kategoria ta odnoszona jest do nierozstrzygniętych w danym momencie szczegółowych problemów ze sfery empiryczno-przyrodniczej, które tymczasowo nie mają naukowego wyjaśnienia. Uznaje się, że żadna $\mathrm{z}$ tych luk nie powinna być zapełniania przez wyjaśnienia religijne, odwołujące się do czynników nadnaturalnych.

Do strategii tej należy także zastępowanie tradycyjnej koncepcji stworzenia jako specjalnego aktu czy aktów Boga, mających miejsce w przeszłości, koncepcją stałego stworzenia (continuing creation). W tym ujęciu stworzenie nie zakończyło się, lecz dokonuje się nieustannie. Zgodnie z uzasadnieniem przyjęcia tej opcji, podanym przez Iana G. Barboura, czołowego przedstawiciela teizmu naturalistycznego, wiąże się ono z obrazem świata dostarczanym przez współczesną naukę. W średniowieczu przyjmowano, że Bóg stworzył wszystko na początku i odtąd podtrzymuje świat $\mathrm{w}$ istnieniu, zarządza nim, ale nie wprowadza, nie stwarza niczego nowego. Tymczasem zgodnie $\mathrm{z}$ obecnym naukowym obrazem świata w historii kosmosu pojawią się nowe rzeczy, świat nie jest skończonym produktem: „Świat znany dzisiejszej nauce jest dynamiczny i niekompletny. Wszechświat nasz nie jest skończony, lecz podlega ciągłemu procesowi stawania się. Powstanie życia z materii równie dobrze może wyrażać boską twórczość jak przyjmowane [w tradycyjnej teologii - PB] pierwotne stworzenie materii «z niczego». Stworzenie dokonuje się wraz z upływem czasu». ${ }^{18}$

$\mathrm{W}$ istocie $\mathrm{w}$ celu uzgodnienia religii z nauką tradycyjna religijna koncepcja stworzenia zostaje tu odrzucona i zastąpiona koncepcją opatrzności. Barbour wskazuje na występujące w tradycji trzy różnice między koncepcjami stworzenia i opatrzności. Po pierwsze, stworzenie dokonało się na początku, a opatrzność to późniejsze działania Boga. Po drugie, pod względem ontologicznym, Bóg stwarza z niczego, natomiast opatrzność polega na realizacji Bożych celów przy użyciu bytów stworzonych. Po trzecie, stworzenie wyraża Bożą suweren-

\footnotetext{
${ }^{18}$ Ian G. BARBour, Issues in Science and Religion, Harper and Row, New York - Hagerstown - San Francisco — London 1971, s. 385.
} 
ność i transcendencję, zaś opatrzność wyraża się przez Bożą immanencję w przyrodzie i podporządkowanie przyrody stałym prawom. ${ }^{19}$ Jak stwierdza Barbour, „Jeśli stworzenie trwa nieustannie, to pierwsze dwie różnice znikają”. Nie ma więc różnicy między stwarzaniem stałym a opatrznością, jeśli chodzi o kwestie czasowości i statusu ontycznego. „Jeśli czas jest wieczny, to nie było ani żadnego początku, ani żadnego stanu «nihilo», a Bóg nieustannie działa wraz ze swym stworzeniem. Nawet jeśli czas jest skończony, to stworzenie dokonuje się w trakcie całego jego trwania i poprzez inne byty". ${ }^{20}$ Bóg więc nie tylko zwyczajnie działa, ale i stwarza nieustannie.

W tym ujęciu nie ma więc znaczenia, czy materia jest wieczna, czy została stworzona $\mathrm{z}$ niczego, czy Wszechświat miał czasowy początek, czy istnieje wiecznie, czy życie albo człowiek są wynikiem nadnaturalnej ingerencji, czy tworami powstałymi zgodnie z prawami przyrodniczymi. To, co tradycyjnie uznawane było za Boże działanie opatrznościowe, w nowym ujęciu zostaje nazwane działalnością stwórczą. Oczywiście każda naukowa teoria mówiąca o powstaniu czy wieczności Wszechświata będzie zgodna z religijną ideą stworzenia, jeśli przez „stworzenie” będzie się rozumiało metafizyczną koncepcję, według której Bóg nieustannie podtrzymuje w istnieniu wszystko, co według nauki ma miejsce.

Ujęcie, w którym postuluje się odwołanie do działania czynników nadnaturalnych przy wyjaśnianiu jakichś szczegółowych zdarzeń czy cech świata przyrodniczego, przedstawia się tu dyskredytująco jako koncepcję „Boga kapryśnego”, ${ }^{21}$ „Boga magika”, ${ }^{22}$ „Boga zapchajdziury” czy „Boga luk” (God of the

\footnotetext{
${ }^{19}$ Por. BARBour, Issues..., s. 385.

${ }^{20}$ BARBour, Issues..., s. 385.

${ }^{21}$ „Jakakolwiek by nie była relacja Boga do świata, musi być ona wierna a nie kapryśna, ra czej oparta na regularnościach i prawach niż doraźnym, tymczasowym działaniu" (John C. PoLKINGHORNE, Jeden świat. Wzajemne relacje nauki i teologii, przeł. Marek Chojnacki, Wydawnictwo WAM, Kraków 2008, 139).

${ }^{22}$ Według Kennetha R. Millera ujęcie interwencjonistyczne w kwestii pochodzenia gatunków „,...] czyni okropną szkodę koncepcji Boga, przedstawiając go jako magika, który co jakiś czas stwarza i stwarza i potem znów stwarza w kolejnych epokach geologicznych. [...] Bóg nie jest magikiem, który robi tanie sztuczki" (Kenneth R. Miller, Finding Darwin's God: A Scientist's Search for Common Ground Between God and Evolution, Cliff Street Books, New York
} 
gaps). ${ }^{23}$ Koncepcja ta uznawana jest za szkodliwą dla religii, gdyż rozwój nauki sprawia, iż kolejne luki, w których umieszczano działanie Boga, zostają z czasem zastąpione przez wyjaśnienia naukowe, co prowadzi do dyskredytowania religii. Jak wyraża to Polkinghorne:

Rozwój wiedzy [...] sprawił, że powoływanie się na Boga traktowanego jako «zapchajdziura» [...], którego jedyną rolą jest thumaczenie tego, co naukowo niewyttumaczalne, stawało się coraz mniej wiarygodne. $Z$ pewnością jest wiele rzeczy, których nie rozumiemy. [...] Nie mamy jednak powodów by sądzić, iż na pytania zadawane przez naukę nie znajdą się w końcu naukowe odpowiedzi [...].

Bóg «zapchajdziura» umarł [...]. ${ }^{24}$

Zatem należy się spodziewać, że wszystkie zagadnienia badane przez naukę znajdą swoje naturalistyczne wyjaśnienia. Rozwój nauki powoduje więc, że powinno się odrzucić koncepcję „Boga luk”. Według zaś Hellera krytykowana koncepcja jest fałszywa ze względów czysto teologicznych: „Bóg, który ma wypełnić braki naszej wiedzy o świecie, jest po prostu teologicznym fałszem". ${ }^{25}$ Nie oznacza to jednak, że wyklucza się tu wszelką aktywność Boga. Odrzucenie idei aktywności Boga po stworzeniu świata jest charakterystyczne dla deizmu, który z punktu widzenia chrześcijaństwa jest herezją. By uniknąć deizmu, różni teistyczni naturaliści przyjmują różne koncepcje nieinterwencjonistycznego działania Boga w świecie.

1999, s. 128).

${ }^{23}$ To najpopularniejsze określenie pochodzi od Dietricha Bonhoeffera (por. Nicholas SAUNDERs, Divine Action and Modern Science, Cambridge University Press, Cambridge 2002, s. 96). Bonhoeffer twierdził, że niewłaściwe jest używanie wyjaśnień odwołujących się do Boga, gdy wiedza ludzka jest niepełna. W liście do Eberharda Bethge'a pisał, że ,,[...] Powinniśmy doszukiwać się Boga w tym, co wiemy, a nie w tym, czego nie wiemy [...]" (Dietrich Bonhoeffer, Letters and Papers from Prison: The Enlarged Edition, SCM Press, London, list do Eberharda Bethge'a z 29 maja 1944 [cyt za: SAunders, Divine Action..., s. 96]). s. 9.

${ }^{24}$ Polkinghorne, Nauka i stworzenie..., s. 41. Por. też Polkinghorne, Nauka i stworzenie...,

${ }^{25}$ Michał Heller, „Z dziejów stosunków między kreacjonizmem i ewolucjonizmem”, w: Michał Heller i Józef Życiński, Dylematy ewolucji, Universum, Wydawnictwo Biblos, Tarnów 1996, s. 171 [160-172]. 
Zgodnie z popularną koncepcją aktywność Boga $\mathrm{w}$ świecie polega nie na specjalnym ingerowaniu w losy świata, lecz na tym, że Bóg podtrzymuje świat $\mathrm{w}$ istnieniu, a przez to uczestniczy w każdym zachodzącym $\mathrm{w}$ nim procesie. W filozofii tomistycznej mowa jest o Bogu jako Pierwszej Przyczynie oraz o bytach stworzonych jako przyczynach wtórnych czy narzędnych, poprzez które działa Bóg. Tego typu pogląd wyrażony jest w streszczeniu stanowiska Tomasza z Akwinu podanym przez Piotra Lichacza: „Zależność bytów stworzonych od przyczyny ich istnienia jest według Akwinaty dokładnie ta sama na początku trwania bytów stworzonych, jak i w całym ich trwaniu [...] Jeśli rozumieć stworzenie jako działanie pierwszej przyczyny, to tym samym działaniem jest pierwotne stwarzanie, jak i podtrzymywanie w istnieniu. Inaczej mówiąc, gdyby ustało stwórcze działanie Boga, stworzenie przestałoby istnieć. Cokolwiek istnieje, niezależnie jak długo istnieje i w wyniku jakich procesów i elementów powstało, jest w każdym wypadku wynikiem stwórczego działania Boga". ${ }^{26}$ Bóg jest zatem bardzo aktywny, albowiem w każdym momencie stwarza świat. Może być więc aktywny bez naruszania porządku naturalnego, po prostu podtrzymując ten porządek $\mathrm{w}$ istnieniu.

Popularne wśród teistów naturalistycznych jest podkreślanie immanentnej obecności Boga w świecie, wyrażane przez nich jako koncepcja właśnie podtrzymywania świata $\mathrm{w}$ istnieniu czy obecności w prawach przyrody. Jak pisał Arthur Peacocke:

[...] współczesny teista chrześcijański, kładący nacisk na immanentną stwórczą aktywność Boga we Wszechświecie, musi uznać, że Bóg czyni to wyłącznie za pomocą praw i prawidłowości przyrody. [...] Jeśli Bóg jest w ogóle obecny w kosmicznym procesie ewolucji materii, to jest On w nim wszechstronnie, we wszystkich jego aspektach i potencjalnościach, niezależnie od tego, czy realizują się one czy nie i utrzymuje On świat $\mathrm{w}$ istnieniu siłą swej woli [...]. ${ }^{27}$

\footnotetext{
${ }^{26}$ Piotr Lichacz, „Czy stworzenie wyklucza ewolucję?”, w: Bogusław Kochaniewicz (red.), Teologia św. Tomasza z Akwinu dzisiaj, Uniwersytet im. Adama Mickiewicza, Poznań 2010, s. 90 [71-94] (cyt. za: CHABEREK, ,Św. Tomasz z Akwinu a ewolucjonizm...”, s. 41-42).

${ }^{27}$ Arthur Peacocke, Teologia i nauki przyrodnicze, przeł. Leszek M. Sokołowski, Znak, Kraków 1991, s. 171.
} 
Bóg jest więc obecny we wszystkim, co się wydarza, we wszystkich aspektach świata, a nawet w potencjalnościach, które się nie realizują, i siłą swojej woli podtrzymuje świat $\mathrm{w}$ istnieniu.

Abp Józef Życiński proponował nieinterwencjonistyczną interpretację ewolucjonizmu, w tym koncepcji pochodzenia człowieka. Według Życińskiego aktywność Boga przy stworzeniu człowieka polegała na (stałej) obecności Boga w prawach przyrody, w tym w procesie ewolucji. Jak pisał:

Procesu tego nie należy ujmować w sposób zdominowany przez naiwne antropomorfizmy. Pojawiają się one wówczas, gdy ewolucję na poziomie zwierzęcym ujmowalibyśmy wyłącznie w kategoriach doboru naturalnego, a dopiero przy powstaniu człowieka wprowadzilibyśmy specjalną ingerencję stwórczą Boga. Boski Logos jest immanentnie obecny w całym procesie twórczego rozwoju wszechświata. Proces tworzenia trwa w każdej epoce i nasze „trwanie w istnieniu” jest tego przejawem. ${ }^{28}$

Zatem według tego rozumienia działania Boga w świecie polega ono na stałej obecności Boga w procesach przyrodniczych, których naturalnego porządku Bóg nie narusza. Stąd wystarczalność naukowych wyjaśnień naturalistycznych w odniesieniu do wszelkich zdarzeń przyrodniczych. Nie ma więc konfliktu między nauką a religią, gdyż działanie Boga ma miejsce w sferze metafizycznej, niedostępnej nauce, zaś podlegający kompetencji nauki porządek przyrodniczy nie jest przez to działanie naruszany, a wręcz jego stałość jest podtrzymywana przez immanentną obecność Boga w niezmiennych prawach przyrody.

Oczywiście twierdzenie, że Bóg podtrzymuje każdy naturalny proces $\mathrm{w}$ istnieniu, ma charakter zupełnie nieempiryczny. Żadne dane empiryczne mu nie zaprzeczają, ani go nie potwierdzają. Zgodne jest więc $\mathrm{z}$ wieloma ontologiami przyrody, czy to ewolucjonistycznymi, czy hylemorficznymi, czy jeszcze innymi. Takie rozumienie działalności Boga w świecie łatwo więc pogodzić $\mathrm{z}$ opisem przyrody, jaki prezentuje współczesny naturalizm naukowy.

Ten sposób godzenia nauki i religii proponuję określić jednak jako „zbyt łatwy". Ze względu na interwencjonistyczny charakter tradycyjnego teizmu man-

\footnotetext{
${ }^{28}$ JózeF ŻY YCIŃSKI, Bóg i ewolucja. Podstawowe pytania ewolucjonizmu chrześcijańskiego, Prace Wydziału Filozoficznego, t. 89, Wydawnictwo TN KUL, Lublin 2002, s. 57 [wyróżnienia dodane].
} 
kamentem tego „zbyt łatwego” sposobu godzenia nauki i religii jest to, że jest on jednocześnie zbyt kosztowny. Z jednej strony koncepcja Boga jako ontycznej podstawy czy bytu koniecznego albo koncepcja mówiąca o stałym podtrzymywaniu świata $\mathrm{w}$ istnieniu należą do tradycji teizmu chrześcijańskiego. $\mathrm{Z}$ drugiej strony w zaprezentowanej tu strategii wymaga się porzucenia szerokiego zakresu twierdzeń i argumentacji religijnych, odrzucenia wartości poznawczej różnych relacji biblijnych, hagiograficznych czy związanych z kultem świętych miejsc lub obrazów, odrzucenia ważnych koncepcji i relacji dotyczących cudów czy ingerencji dokonywanych w świecie przez niższe byty nadnaturalne (jak na przykład tzw. opętanie demoniczne), które są istotne dla teizmu chrześcijańskiego w ogóle lub przynajmniej dla niektórych jego nurtów.

Krytyka koncepcji interwencjonistycznego działania Boga występująca w ramach teizmu naturalistycznego zasadza się na przyjęciu filozoficznego założenia, które leży u podstaw współczesnego rozumienia naukowości. Jest to tzw. „założenie naturalizmu metodologicznego”, według którego nauce wolno wyjaśniać wszelkie zjawiska wyłącznie przez odwołanie do czynników naturalnych. Michał Heller, katolicki ksiądz i jednocześnie fizyk, wprost stwierdza, że nauce nie wolno nigdy rezygnować z wyjaśnień naturalistycznych. Jak pisze, „W nauce nigdy nie wolno rezygnować z wyjaśnienia jakiegoś «materialnego zjawiska» przy pomocy innego «materialnego zjawiska»". ${ }^{29}$ Przy uznaniu zasadniczej adekwatności naukowego obrazu świata przyjęcie naturalizmu metodologicznego jako właściwej dyrektywy poznawczej prowadzi do przyjęcia ontologii, w której w przyrodę nie ingeruje nic spoza niej. Przyjęcie przez teistycznych naturalistów obrazu świata, w który nie ingeruje nic z zewnątrz, którego naturalny porządek nie jest naruszany, jest więc wynikiem przyjęcia założeń obcych tradycyjnemu teizmowi.

Cytowany wcześniej Polkinghorne twierdził, podobnie jak większość teistów naturalistycznych, że to rozwój nauki uzasadnia odrzucenie koncepcji o zachodzeniu w świecie zdarzeń, dla których nie ma adekwatnych wyjaśnień naturalistycznych. Rozwój ten polegać ma na rozwiązywaniu coraz większej liczby problemów, które wcześniej uznawano za wymagające odwołania do wy-

\footnotetext{
${ }^{29}$ Michał Heller, Sens życia i sens Wszechświata. Studia z teologii wspólczesnej, Wydawnictwo Biblos, Tarnów 2002, s. 44-45.
} 
jaśnień natury religijnej. Wbrew temu stanowisku, w dalszej części wykażę przez odwołanie do modelu poziomów analizy, że odrzucenie interwencjonizmu przez teistów naturalistycznych wynika z przyjęcia określonych, obcych teizmowi założeń filozoficznych, a nie po prostu z postępu empirycznego nauki. $\mathrm{Na}$ podstawie różnic i związków między poziomami analizy twierdzeń na temat świata wskażę na mankamenty argumentacji zawartej w niedawnych publikacjach Chaberka oraz przedstawionej wyżej argumentacji teistów naturalistycznych.

\section{Poziomy analizy w dyskusji nad relacją nauki i religii}

Jeśli przez relację między nauką a religią rozumieć relację między przyjmowanymi przez nie twierdzeniami na temat rzeczywistości, to dla właściwego ujęcia tej relacji konieczne jest zwrócenie uwagi na różnice w rozumieniu kluczowych kategorii używanych w obrębie tych dwóch dziedzin. Nie mam tu na myśli tylko tego, że ta sama kategoria ma inne znaczenie, gdy występuje w twierdzeniach religijnych, a inne, gdy pojawia się w koncepcji naukowej. Ważna część nieporozumień występujących w rozważaniach nad relacją nauki i religii wynika ze zmiany znaczenia danej kategorii używanej w danym dyskursie, czy to religijnym, naukowym czy filozoficznym, wynikającej z tego, że wykorzystywana jest ona w obrębie tego samego dyskursu na różnych poziomach analizy.

Mówiąc o różnych poziomach analizy mam na myśli podział twierdzeń na temat rzeczywistości, rozróżniając je pod względem stopnia empiryczności rozumianego jako możliwość empirycznego testowania adekwatności tych twierdzeń. W punkcie poświęconym wykorzystaniu filozofii tomistycznej w rozważaniach nad relacją nauki i religii wskazałem dwa przykłady, w których mieliśmy do czynienia $\mathrm{z}$ wątpliwym sposobem ustalenia relacji między twierdzeniami nauki i religii. Przedstawiony niżej model poziomów analizy stanowić będzie dobrą platformę dla wykazania istoty mankamentów występujących w tych przykładach oraz dla podania charakterystyki innych szczegółowych sposobów ujmowania relacji nauki i religii. Nie przedstawiam tu jednak pełnego opracowania tego modelu, a jedynie jego zarys. 
Wyróżnienie poszczególnych poziomów polega tu na abstrahowaniu i izolowaniu różnego rodzaju twierdzeń z całościowych systemów pojęciowych czy ujęć, których stanowią niekiedy integralne części. Nie przedstawia się więc tu „naturalnego" dla nich sposobu występowania. Stąd ukazane tu relacje między twierdzeniami różnych poziomów mogą różnić się od relacji między tymi twierdzeniami, jakie zazwyczaj przypisuje się im w dyskursie z zakresu analiz relacji nauki i religii. Model ten ma wskazać pewne ogólne prawidłowości w relacjach między wymienionymi poziomami, co powinno ułatwić właściwe ujęcie relacji między twierdzeniami w stanowiskach przyjmowanych faktycznie. Jak jednak wspomniałem wyżej, w niniejszym opracowaniu podany zostanie jedynie zarys tego modelu, w tym i prawidłowości relacji między poziomami analizy.

Przeprowadzenie poniższego podziału w ten a nie inny sposób uzasadnione jest przez kontekst problemowy relacji nauki i religii. Przy analizie innych problemów podział ten mógłby przebiegać być może w inny sposób, różniąc się przykładowo w kwestii zaliczenia poszczególnych twierdzeń do tego czy innego poziomu analizy.

Kategorie i twierdzenia dotyczące natury rzeczywistości, jej składników, struktury i procesów w niej zachodzących proponuję podzielić na następujące rodzaje i odpowiadające im poziomy analizy:

Poziom 1 (,głębokiej metafizyki”) obejmuje przede wszystkim najbardziej ogólne empirycznie neutralne twierdzenia na temat bytu czy istnienia jako takiego. Przykładowe tezy występujące na tym poziomie analizy to: „Byt jest, a niebytu nie ma”; „Byt bytuje, nicość nicościuje” i tym podobne. Do tego zakresu zaliczałyby się też niektóre twierdzenia teologii trynitarnej o relacji między osobami Trójcy Świętej, o Bogu jako bycie koniecznym, czy o stałym podtrzymywaniu świata w istnieniu przez Boga. Żadne szczegółowe badania empiryczne nie rozstrzygają o trafności ustaleń dokonanych na tym poziomie. W tym sensie można powiedzieć, że są one zupełnie pozbawione treści empirycznej.

Twierdzenia tego poziomu są także zupełnie neutralne wobec twierdzeń ze wszystkich niższych poziomów, nie tylko twierdzeń o charakterze empirycznym, które należą do poziomu najniższego. Przykładowo stanowisko, że Bóg będący bytem koniecznym nieustannie stwarza świat, podtrzymując każdy proces przyrodniczy $\mathrm{w}$ istnieniu, bez trudu można uzgodnić $\mathrm{z}$ alternatywnymi sta- 
nowiskami w sporze nominalizmu z realizmem metafizycznym (Poziom 2), interwencjonizmu $\mathrm{z}$ antyinterwencjonizmem (Poziom 3), kreacjonizmu $\mathrm{z}$ ewolucjonizmem (według rozumienia tego sporu zgodnie z poziomem 4) czy dowolnymi twierdzeniami z poziomu najniższego. Widać więc, jak rzeczywiście nazbyt „łatwy” jest wskazany wyżej sposób godzenia nauki i religii poprzez redukcję koncepcji działania Bożego i stworzenia do koncepcji stałego podtrzymywania świata w istnieniu czy stałego stworzenia.

Poziom 2 („,metafizyki płytszej”) obejmuje twierdzenia o racjonalności świata, o istnieniu lub nieistnieniu racjonalnego Stwórcy jako podstawy tej racjonalności; ogólne twierdzenia o deterministycznym lub indeterministycznym charakterze tego, co istnieje; o celowości i braku celowości świata jako takiego. Tu można umiejscowić dyskusje dotyczące wartości czy sensu tego, co istnieje. $\mathrm{Na}$ tym poziomie występowałaby dyskusja między realizmem a nominalizmem w sporze o istnienie desygnatów pojęć ogólnych. Zatem występowałyby tu twierdzenia o istnieniu świata idei, będącego wzorcem dla świata rzeczy, czy twierdzenia, że wszystkie zdarzenia w świecie są wytworem ślepego przypadku.

Twierdzenia $\mathrm{z}$ tego poziomu także nie podlegają testowaniu empirycznemu i przyjęcie ich nie jest wynikiem argumentów empirycznych. Jednak mogą one służyć jako założenia dla interpretacji twierdzeń związanych ze stosowaniem naukowych metod poznawczych. Przykładowo założenie o racjonalności i poznawalności świata może być uznane za ugruntowujące możliwość prowadzenia badań naukowych. Einstein, który nie wierzył w istnienie Boga ingerującego w przyrodę, mówił o religijnym charakterze nauki właśnie w sensie naukowego obrazu Wszechświata jako bytu racjonalnego, inteligibilnego. ${ }^{30}$

Twierdzenie o istnieniu racjonalnej istoty, będącej Stwórcą świata, może być traktowane jako wyjaśniające pochodzenie racjonalności świata, która zakładana jest przy prowadzeniu empirycznych badań nauki. W każdym razie przyjęcie lub odrzucenie tych twierdzeń nie jest związane $\mathrm{z}$ argumentacją odwo-

\footnotetext{
${ }^{30}$ „Trudno byłoby znaleźć jakiś głębiej drążący umysł naukowy, którego nie cechowałaby swoista religijność. [...] Religijność jego polega na pełnym zachwytu zdumieniu harmonią prawidłowości przyrody, w której objawia się rozum tak przemożny, że wszystko, co rozumne w ludzkim myśleniu i decydowaniu jest wobec niego zupełnie bladym odblaskiem" (Albert Einstern, „Religijność badań naukowych”, w: Albert Einstein, Pisma filozoficzne, IFiS PAN, Warszawa 1999, s. 218 [217-218])
} 
łującą się do doświadczenia, lecz wcześniejsze przyjęcie tych twierdzeń wpływa na interpretację doświadczenia. Na tym poziomie analizy wpływ na interpretację doświadczenia wyraża przykładowo argumentacja, według której tylko oczami wiary można dostrzec w przyrodzie działanie Boga czy celowość w procesie ewolucji. Ponieważ na tym poziomie występują sądy wartościujące, to przez odwołanie do twierdzeń $\mathrm{z}$ tego poziomu uznaje się uprawianie nauki za zajęcie ważne i sensowne. Żadne ustalenia naukowe co do danych empirycznych, wyrażone $\mathrm{w}$ twierdzeniach najniższego poziomu, nie rozstrzygają natomiast problemu wartości nauki jako takiej.

Poziom 3 (,ontologii przyrody”). Jest to ostatni z poziomów analizy, którego kategorie zasadniczo nie występują $\mathrm{w}$ artykułach publikowanych w czasopismach naukowych, a przynajmniej nie występują tam, gdy dana dziedzina nauki znajduje się w okresie rozwoju określanym przez Kuhna jako „nauka normalna". Twierdzenia $\mathrm{z}$ tego poziomu wpływają jednak zasadniczo na treść teorii naukowych, stanowiąc ich integralną część, tak że jedynie w analizie abstrakcyjnej można je jakby „sztucznie” odseparować od innych twierdzeń z niższych poziomów analizy, występujących w konkretnych koncepcjach naukowych. $\mathrm{Na}$ tym poziomie występują dyskusje nad trafnością ujęć procesów przyrodniczych wyrażonych w sporach między determinizmem i indeterminizmem, mechanicyzmem i finalizmem, redukcjonizmem i antyredukcjonizmem, atomizmem i hylemorfizmem, interwencjonizmem i antyinterwencjonizmem oraz wyznaczony przez ten kontekst spór ewolucjonizmu i kreacjonizmu, dyskusje nad relacją ciała i umysłu czy kompatybilicystycznym i inkomaptybilicystycznym ujęciem wolnej woli człowieka i tym podobne.

$\mathrm{Na}$ tym poziomie dokonuje się więc rozstrzygnięć na temat deterministycznej czy indeterministycznej interpretacji fizyki kwantowej. Do tego poziomu analizy odnosiłaby się wypowiedź Einsteina, że „Bóg nie gra w kości”, w której krytykował kopenhaską interpretację fizyki kwantowej. Do tego poziomu należą tezy o determinizmie równań teorii chaosu. $\mathrm{Na}$ tym poziomie występują twierdzenia neodarwinizmu o przypadkowym, niekierowanym charakterze procesu ewolucji jako wyniku przypadkowych mutacji i niekierowanego doboru naturalnego czy twierdzenia o subtelnym, niedostrzegalnym dla nauki wpływie Boga na kierunek ewolucji. 
Poziom 4 (ontologii ogólnych kategorii używanych w sformułowaniach praw i teorii przyrodniczych $\mathbf{i}$ w koncepcjach religijnych). Ten oraz następny, ostatni poziom analizy, jeśli odnieść je do obszaru nauki, charakteryzują się tym, że kategorie, będące tu przedmiotem dyskusji, występują w ściśle naukowych artykułach publikowanych w czasopismach z dziedziny nauk przyrodniczych (empirycznych). Na tym poziomie mamy do czynienia z ogólnymi twierdzeniami na temat przyrody, dotyczącymi zależności między zdarzeniami, własnościami czy mówiącymi o strukturze przyrody, które wyrażone są w postaci praw i teorii naukowych. Byłyby więc to takie twierdzenia jak „Ziemia krąży wokół Słońca”, „Średnia odległość od środka Ziemi do środka Księżyca to 384403 km”; „Każdy kruk jest czarny”, „Ślimak winniczek składa od 20 do 60 jaj” czy „F = ma”. Znalazłyby się tu równania Maxwella, równania Schrödingera, prawo rekapitulacji w biologii ewolucyjnej, czy Freuda teoria roli kompleksu Edypa w rozwoju osobowości i tym podobne. Do tego poziomu zaliczałoby się prawo doboru naturalnego i teza o transformizmie gatunkowym czy hylemorficzne ujęcie mówiące o stałości gatunków (mielibyśmy tu więc do czynienia $\mathrm{z}$ innym, bardziej empirycznym, ujęciem kontrowersji ewolucjonizm-kreacjonizm niż na wyższym poziomie analizy).

Z punktu widzenia zaproponowanego tu modelu poziomów analizy można zauważyć, że przedstawiona przez Chaberka argumentacja na rzecz niespójności wewnętrznej ewolucjonizmu, gdy odwoływał się przykładowo do niemożności transformacji gatunków, w istocie dotyczyła zagadnień analizowanych na tym poziomie i związanych z ujęciem hylemorficznym. Chaberek twierdził tymczasem, że wskazywany przez niego problem dotyczy niezgodności transformizmu $\mathrm{z}$ realizmem metafizycznym. Realizm metafizyczny znajduje się jednak na wyższym poziomie analizy niż zagadnienia transformizmu gatunkowego i stanowiska te są względem siebie neutralne. Mam na myśli to, że bez naruszania zasad logiki można uznawać za prawdziwe twierdzenia realizmu metafizycznego (jako stanowiska przeciwnego nominalizmowi), a jednocześnie przyjmować stanowisko transformizmu gatunkowego na poziomie ontologii przyrody czy na niższych, bardziej empirycznych poziomach analizy. Realizm metafizyczny, jako stanowisko o istnieniu platońskich wzorców poszczególnych gatunków w świecie Idei czy umyśle Boga, nie wyklucza poglądu, że przyroda, w trwającym miliony lat procesie ewolucji, realizuje te wzorce poprzez przekształcanie się jed- 
nych gatunków przyrodniczych (czyli nie idealnych, niezmiennych wzorców) w inne. Względem koncepcji realizmu metafizycznego neutralne są więc także rozważania na temat tego, czy gatunki powstały w wyniku Boskiej interwencji czy na drodze doboru naturalnego.

Zaliczałyby się tu też ogólne twierdzenia o zależnościach między składnikami świata przyrodniczego występujące $\mathrm{w}$ astrologii, alchemii czy w myśleniu magicznym. Przypomnijmy tu charakterystykę magii dokonaną przez Frazera, według którego jest ona nauką o związkach przyczynowych zachodzących w świecie, tyle że błędnie ujmującą te związki.

$\mathrm{Z}$ zakresu analiz religijnych mielibyśmy tu do czynienia $\mathrm{z}$ twierdzeniami dotyczącymi warunków skutecznej modlitwy czy medytacji. Przykładowo znalazłyby się tu twierdzenia o skutecznych sposobach przeprowadzania egzorcyzmów, o tym, że modlitwa świętych jest bardziej skuteczna niż grzeszników i tym podobne. W Jogasutrach Patandżalego znajduje się cały szereg opisów prawideł występujących na drodze jogi, na podstawie których jogin zdolny jest do osiągnięcia różnych nadzwyczajnych skutków, takich jak unoszenie się w powietrzu czy stawanie się niewidzialnym. Sformułowania tych prawideł jogi także zaliczałyby się do tego poziomu analizy.

Poziom 5 (,analizy empirycznej”) obejmuje szczegółowe twierdzenia na temat rzeczywistości empirycznej (przyrodniczej), mające charakter twierdzeń empirycznych. Są to twierdzenia o zajściu określonego zdarzenia czy stanu rzeczy w danym miejscu i czasie. Zaliczałyby się tu między innymi twierdzenia określane w historii metodologii nauki mianem „zdań protokolarnych”, „twierdzeń szczegółowych”, ,zdań obserwacyjnych” czy tzw. „potencjalnych falsyfikatorów" (pomijam tu analizę różnych zastrzeżeń co do czysto empirycznego ich charakteru). Sądy występujące na tym poziomie służą więc testowaniu twierdzeń z poziomu bezpośrednio wyższego.

Przykładowe twierdzenia z tego poziomu analizy to: „Ten kruk jest czarny”; „Wskazówka woltomierza wychyliła się o x stopni”, „Wysokość Księżyca nad horyzontem wynosiła x stopni”, „Skamieniałość znajdowała się w warstwie datowanej na $\mathrm{x}$ lat”, „Kazimierz Wielki był ostatnim królem Polski z dynastii Piastów”, ,Jezus żył w Palestynie w I wieku n.e.”, „Mojżesz przeszedł z Izraelitami przez Morze Czerwone”, „W Kanie Galilejskiej woda zamieniła się w wino”, 
„Jezus szedł po wodzie” czy „Po urodzeniu Jezusa Maryja pozostała dziewicą” . Zaliczyłbym tu też twierdzenie, że początek Wszechświata miał miejsce około 13,7 mld lat temu, ustalenia na temat kolejnych faz rozwoju Wszechświata czy szczegółowe twierdzenia o wyłanianiu się poszczególnych gatunków organizmów w historii życia na Ziemi, w tym o powstaniu człowieka.

Twierdzenia z poziomu bezpośrednio wyższego służą wyjaśnieniu zdarzeń opisanych $\mathrm{w}$ zdaniach $\mathrm{z}$ tego najniższego poziomu poprzez odwołanie się do różnorakich związków przyczynowych, strukturalnych czy innych, które to związki opisane są przez prawa, teorie i reguły występujące na tym bezpośrednio wyższym poziomie analizy. Na tej zasadzie położenie Księżyca w określonym czasie wyjaśnia się przez odwołanie do struktury Układu Słonecznego i praw rządzących ruchem ciał niebieskich; wyjaśnienia występowania danej skamieniałości w określonej warstwie geologicznej odwołują się do praw, na jakich bazują różne metody datowania, czy do teorii ewolucji. Odnośnie do powstania określonych gatunków występowałyby tu wyjaśnienia odwołujące się do twierdzeń o ogniwach pośrednich, prawa doboru naturalnego, mutacji genetycznych i tym podobne.

Wyjaśnienie samego powstania Wszechświata stanowi tu szczególną trudność ze względu na wyjątkowość tego zdarzenia. Naukowe, naturalistyczne hipotezy wyjaśniające odwołują się tu między innymi do koncepcji fluktuacji próżni kwantowej, teorii wszechświata cyklicznego czy teorii mówiącej o wyłanianiu się wszechświatów w wyniku zderzania bran. Można wskazać tu dwie trudności dla naukowego wyjaśnienia rozumianego jako podanie przyczyn Wielkiego Wybuchu. Jedną jest załamywanie się znanych obecnie fizyce praw przyrody w osobliwości, jaką był Wielki Wybuch. Drugi problem związany jest z kwestią Pierwszej Przyczyny: nawet gdyby zdołano ustalić prawidłowości, na podstawie których udałoby się w pełni opisać moment początkowy, to i tak pozostawałoby pytanie o to, dlaczego prawidłowości te są takie a nie inne, albo dlaczego w ogóle cokolwiek istniało. Pytanie, dlaczego w ogóle cokolwiek istnieje, należy jednak do zagadnień, które zaliczają się do najwyższego poziomu analizy, określonego przeze mnie mianem poziomu głębokiej metafizyki, którego rozstrzygnięcia są empirycznie neutralne. 
W przypadku twierdzeń o charakterze religijnym byłaby tu mowa o interwencyjnym działaniu nadprzyrodzonym jako przyczynie zajścia określonych zdarzeń. Tego poziomu dotyczą więc dyskusje, czy w poszczególnych przypadkach można mówić o występowaniu szczegółowych luk w naukowym, naturalistycznym opisie rzeczywistości. Przyjęcie lub odrzucenie stanowiska interwencjonistycznego na wyższym poziomie wpływa więc na przyjęcie określonego stanowiska w kwestii możliwych rozwiązań szczegółowych problemów na tym poziomie analizy. $\mathrm{W}$ ten sposób przy przyjęciu interwencjonizmu przejście przez Morze Czerwone, zamiana wody w wino, zmartwychwstanie Jezusa oraz pozostałe cuda opisane w Biblii i inne znane tradycji chrześcijańskiej thumaczone byłyby ingerencją sfery nadnaturalnej. Na tej zasadzie opętanie demoniczne byłoby wyjaśniane jako działanie złego ducha, osobowego bytu niebędącego istotą materialną. Podobnie różne niezwykłe relacje osób, które przeżyły stany bliskie śmierci (NDE - near-death experiences), o „wychodzeniu z ciała” mogłyby na tym poziomie być thumaczone przez odwołanie do funkcjonowania świadomości niezależnie od stanów mózgu. Na tym poziomie alternatywne naukowe twierdzenia wyjaśniające to, co w ujęciu religijnym określane jest opętaniem, czy relacje z doświadczeń NDE odwoływałyby się do kategorii z modelu biopsychospołecznego.

W przypadku problemu powstania Wszechświata wyjaśnienie zgodne z teizmem chrześcijańskim odwoływałoby się do Stwórczego aktu Boga na początku czasu. Należy odróżnić rozumienie koncepcji stworzenia jako działania Boga powodującego powstanie Wszechświata $\mathrm{w}$ określonym momencie przeszłości od rozumienia „stworzenia” jako koncepcji głoszącej ontyczne pierwszeństwo Boga czy stałe podtrzymywanie świata $w$ istnieniu przez Boga. Te dwa rozumienia należą do różnych poziomów analizy, stąd ich odmienne znaczenia. Ponieważ ostatnie z nich należy do poziomu najwyższego, to charakteryzuje się zerową treścią empiryczną, zatem zgodne jest $\mathrm{z}$ dowolnymi naukowymi rozstrzygnięciami na temat początków czy wieczności Wszechświata.

Podobnie na tym poziomie analizy w przypadku religijnego wyjaśnienia stworzenia człowieka znajduje się koncepcja mówiąca o interwencji Boga w przyrodzie. Do tego poziomu zaliczyłbym wypowiedź Piusa XII z encykliki Humani generis, że o ile ciało człowieka może pochodzić od zwierząt niższych, to dusza ludzka powstała w wyniku bezpośredniego działania Boga. Wyjaśnie- 
nia mówiące o stworzeniu człowieka przez Boga jako jedynie Jego stałej obecności $\mathrm{w}$ prawach przyrody, podtrzymywaniu świata, $\mathrm{w}$ tym procesu ewolucji $\mathrm{w}$ istnieniu czy deistyczne ujęcia procesu ewolucji Kosmosu jako zaprogramowanego tak, by po jego rozpoczęciu samoczynnie doprowadził do powstania życia i człowieka należą natomiast do dwóch najwyższych poziomów analizy. Przez to są „łatwym” sposobem pogodzenia nauki i religii poprzez zredukowanie koncepcji religijnej do tezy, którą charakteryzuje brak treści empirycznej.

Empiryczna neutralność poziomów metafizycznych pozwala „rozmyć” znaczenie dowolnych kategorii, które używane na poziomie najniższym mają określoną empiryczną treść. W tym sensie teologiczne rozważania na temat zła i cierpienia $\mathrm{w}$ świecie, gdy prowadzone są na poziomie metafizycznym, mogą prowadzić do twierdzeń, że nic, co się dzieje, nie wymyka się spod ontycznej zależności od Boga, który jest dobry. Niezależnie więc od poszczególnych przypadków zła i cierpienia, stwierdzanych na niższych poziomach analizy, ostatecznie wszystko jest w jakimś sensie dobre. Taka redukcja, stosowana przez niektórych teistycznych naturalistów w stosunku do zagadnienia aktywności Boga w świecie, polega jednak na odrzuceniu ważnej części tradycyjnego dla teizmu chrześcijańskiego rozumienia koncepcji stworzenia i działania Boga czy sfery nadnaturalnej w przyrodzie. Ze stwierdzeniem, że Bóg działa w świecie, związana jest inna koncepcja Jego działania, gdy mowa o podtrzymywaniu świata $\mathrm{w}$ istnieniu czy immanentnej obecności $\mathrm{w}$ prawach przyrody, a inna w przypadku stworzenia duszy ludzkiej zgodnie z ujęciem wyrażonym przez Piusa XII czy ukarania Sodomy i Gomory albo cudownego uzdrowienia zakonnicy chorej na chorobę Parkinsona za wstawiennictwem Jana Pawła II.

Wspomniana redukcja sensu stworzenia i działania Boga w świecie wydaje się dokładnie spełniać warunek pogodzenia nauki i religii podany przez Stephena J. Goulda w jego słynnej zasadzie NOMA, czyli „nienachodzących na siebie urzędów nauczycielskich":

Pierwsze przykazanie wszystkich wersji zasady NOMA może być podsumowane następująco: „Nie będziesz mieszał magisteriów, twierdząc, że Bóg bezpośrednio wywołuje ważne zdarzenia w przyrodzie poprzez szczególne ingerencje, poznawalne wyłącznie przez objawienie i niedostępne nauce". W potocznej mowie określamy owe szczególne ingerencje terminem „cuda” — są zdefiniowane operacyjnie jako wyjątko- 
we i chwilowe zawieszenie praw natury w celu zmiany faktów natury przez boskie fiat [...] NOMA rzeczywiście nakłada to „ograniczenie” na koncepcje Boga. ${ }^{31}$

Nie jest więc tu wykluczony pogląd o istnieniu Boga czy o jakiejkolwiek jego aktywności. Wyklucza się przyjmowanie przez religię interwencji Boskich w obszarze, który w zaprezentowanym tu modelu opisywany jest właśnie na poziomie analiz empirycznych. Tezy o działaniu Boga jako podtrzymywaniu świata $\mathrm{w}$ istnieniu spełniają warunek Goulda, ale znajdują się na poziomie, który charakteryzuje zerowa treść empiryczna. Tymczasem tradycyjny teizm głosi właśnie taką koncepcję Boga i Jego działania w świecie, z którą wiąże się przyjęcie twierdzeń z poziomu empirycznego, w których mowa jest o nadnaturalnej przyczynie poszczególnych zdarzeń opisywanych na tym poziomie.

Zaproponowany przez Goulda model relacji nauki i religii przyjmuje założenia antyinterwencjonizmu z 3. poziomu analiz, który nie jest poziomem twierdzeń empirycznych, lecz założeń filozoficznych. Kazimierz Jodkowski twierdzi, że odrzucenie koncepcji Boskich interwencji w przyrodę całkowicie zmienia religię z teistycznej na deistyczną. ${ }^{32}$ Działanie Boga jako podtrzymywanie świata $\mathrm{w}$ istnieniu jest jednak jakimś działaniem, więc zarzut deizmu wydaje się nieuzasadniony. Jednak model poziomów analizy pozwala zauważyć, że przynajmniej niektóre ważne dla teizmu twierdzenia o specjalnym działaniu Boga w niektórych zdarzeniach w świecie należą do empirycznego poziomu analizy. Na poziomie empirycznym teizm naturalistyczny jest więc nie do odróżnienia od deizmu, ${ }^{33}$ ale także od ateizmu.

\footnotetext{
${ }^{31}$ Stephen Jay Gould, Skały wieków. Nauka i religia w pelni życia, przeł. Jacek Biedroń, Wydawnictwo Zysk i S-ka, Poznań 2002, s. 65-66.

${ }^{32}$ Por. Kazimierz Jodkowski, „Epistemiczne układy odniesienia i «warunek Jodkowskiego»”, w: Anna LATAWIEC i Grzegorz BUGAJAK (red.), Filozoficzne i naukowo-przyrodnicze elementy obrazu świata 7, Wydawnictwo Uniwersytetu Kardynała Stefana Wyszyńskiego, Warszawa 2008, s. 113 [108-123], http://www.nauka-a-religia.uz.zgora.pl/index.php?action=tekst\&id=163 (23.10. 2012).

${ }^{33}$ Jak zauważa Jodkowski odnosząc się teistycznego ewolucjonizmu Van Tilla, „Można powiedzieć, że na płaszczyźnie empirycznej teistyczny ewolucjonizm jest nieodróżnialny od deizmu. Różni się od niego jedynie werbalnie, wskutek ucieczki do sfery metafizycznej. Teistyczny ewolucjonizm w wydaniu Van Tilla jest deizmem wszędzie tam, gdzie możemy coś zaobserwować, zmierzyć czy zbadać. Różni się zaś od niego solennym zapewnieniem, że Bóg jest zawsze i wszędzie aktywnie obecny, mimo iż tej obecności w żaden sposób nigdy i nigdzie wykryć nie
} 
Wykluczenie interwencjonistycznego wyjaśnienia tych zdarzeń nie wynika z samych danych obserwacyjnych czy faktów, lecz z przyjęcia założeń filozoficznych z wyższych poziomów analizy. Dzięki temu modelowi lepiej staje się widoczne, że uległość teizmu naturalistycznego wobec antyinterwencjonistcznego naturalizmu nie jest wymuszona przez „nagie fakty” ujawniane przez naukę, ale przez przyjęcie obcych teizmowi założeń filozoficznych.

Nauka korzysta z różnych założeń pozaempirycznych wywodzących się $\mathrm{z}$ wyższych poziomów analizy występujących $\mathrm{w}$ ramach przedstawionego tu modelu. Przykładowo psychiatra wierzący w istnienie niematerialnych bytów duchowych i możliwość opętania będzie bardziej skłonny wysłać do egzorcysty pacjenta, u którego uzna możliwość wystąpienia tego typu problemu, niż psychiatra nie dopuszczający możliwości opętania demonicznego. Ewentualne powodzenie lub niepowodzenie egzorcyzmu będzie przez obu wyjaśniane przez odwołanie do zupełnie różnych koncepcji związanych z wyższymi niż empiryczne poziomami analizy.

W obszarze dyskusji nad relacją nauki i religii niedostrzeganie związków między różnymi poziomami analizy prowadzi często do tezy o rozdzielności kompetencji nauki i religii głoszącej, że nauka mówi o rzeczywistości empirycznej czy o przyrodzie, a religia - o świecie nadprzyrodzonym. Z punktu widzenia modelu poziomów analizy nie dostrzega się tu wpływu filozoficznych założeń z poziomu nazwanego tu „ontologią przyrody” na ustalenia na niższych poziomach analizy. Tymczasem odrzucenie interwencjonizmu skutkuje wykluczeniem nienaturalistycznych wyjaśnień różnych szczegółowych zdarzeń, które w tradycyjnym teizmie były traktowane jako wynik specjalnego działania sfery nadnaturalnej w świecie empirycznym.

Jeżeli moje analizy są trafne, to niekoniecznie musi występować problem (a przynajmniej nie ma tu konieczności logicznej), o jakim pisze Chaberek, po-

\footnotetext{
jesteśmy i nie będziemy w stanie" (Kazimierz JoDKowski, Metodologiczne aspekty kontrowersji ewolucjonizm-kreacjonizm, Realizm. Racjonalność. Relatywizm, t. 35, Wydawnictwo UMCS, Lublin 1998, s. 54, http://www.nauka-a-religia.uz.zgora.pl/index.php?action=tekst\&id=112 [23. 10.2012]). Dariusz Sagan zauważa, że to samo można powiedzieć o teistycznym ewolucjonizmie Michała Hellera (por. Dariusz SAGAN, „Kardynał Schönborn a stanowisko Kościoła katolickiego wobec sporu kreacjonizmu z ewolucjonizmem", Filozofia Nauki 2006, R. XIV, nr 1 (53) s. 114 [107-118], http://www.nauka-a-religia.uz.zgora.pl/index.php?action=tekst\&id=92 [23.10.2012]).
} 
legający na tym, że zachowanie spójności z teorią ewolucji wymaga odrzucenia realizmu metafizycznego. Można przyjmować teorię ewolucji na poziomie empirycznym i jednocześnie realizm metafizyczny na wyższym poziomie analizy, tak samo jak można w sposób spójny jednocześnie twierdzić, że zachodzi proces transformizmu gatunkowego i że gatunki są stworzone przez Boga, gdy przez „stworzenie" rozumie się należącą do najwyższego poziomu analizy ideę ontycznej zależności świata od Boga. Nie trzeba więc porzucać klasycznej metafizyki, tak ważnej, jak pisze Chaberek, dla chrześcijańskiej tradycji teologicznej, by pozostać w zgodzie z empirycznymi twierdzeniami nauki. System empirycznych twierdzeń nauki wraz z jej ontologią, w której gatunki przechodzą jedne $\mathrm{w}$ drugie, jest $\mathrm{w}$ tym ujęciu neutralny względem głębszej metafizyki realizmu czy teologicznych dogmatów wspomnianych przez Chaberka. Wspomniane problemy teologiczne należą do najwyższych poziomów analizy, niewrażliwych na ustalenia z poziomów niższych. Nie można natomiast pogodzić ontologii ewolucjonizmu $\mathrm{z}$ ontologią średniowiecznego hylemorfizmu, jeśli te alternatywne względem siebie stanowiska umieszczone są na tym samym poziomie analizy.

Problem zgodności lub sprzeczności tomizmu z ewolucjonizmem nie jest więc wystarczająco dobrze postawiony, jeśli sprowadza się do ogólnych pytań, czy Bóg mógł się posłużyć ewolucją, a nawet czy się posłużył. Koncepcja działalności Boga na poziomie jedynie metafizycznym jest neutralna wobec ujęcia ewolucji jako procesu przypadkowego przy rozumieniu kategorii przypadku z poziomów najniższych. Podobnie z twierdzeniami o niekierowanej ewolucji zgodne jest też przeciwne metafizyczne twierdzenie, że żaden nadnaturalny byt nie istnieje i nie podtrzymuje żadnego zdarzenia w świecie.

\section{Przesunięcie autorytetu poznawczego na poziomie ontologii przyrody}

Odwołując się do przedstawionego wyżej modelu poziomów analizy będę tu argumentował, że ontologia przyrody zawarta w założeniach współczesnej nauki nie jest wcale bardziej naturalistyczna niż ontologia hylemorfizmu arystotelesowskiego w przyrodoznawstwie średniowiecznym. Różnica między średniowiecznymi a niektórymi dzisiejszymi ujęciami godzącymi teizm chrześcijański z naukową wizją przyrody (tzw. teistyczny naturalizm) polega na uznaniu auto- 
rytetu nauki nie tylko na poziomie twierdzeń empirycznych, ale też na uległości wobec naturalistycznych przesłanek z poziomów wyższych.

W tym miejscu, mówiąc o odmianach naturalizmu, będę miał na myśli poglądy na temat tego, jak funkcjonuje przyroda, jakiego typu reguły rządzą zdarzeniami przyrodniczymi, jakiego rodzaju byty składają się na świat przyrody, jakie relacje zachodzą między tymi bytami i tym podobne. Innymi słowy, mam na myśli różne odmiany ontologii przyrodniczej, której odpowiada środkowy poziom analizy z wcześniej przedstawionego modelu.

W naturalizmie starożytnym można wymienić, po pierwsze, ontologie przyjmujące ożywiony charakter całej przyrody, dalej ontologie unifikujące całość zjawisk w kategoriach tak czy inaczej rozumianego arche oraz reguł przemian wybranej substancji pierwotnej; następnie atomistyczną koncepcję Demokryta, Leukipposa, a później Epikura (z ważną różnicą między nimi, dotyczącą przypadkowości niektórych ruchów atomów) oraz matematyczno-geometryczną, ugruntowaną $\mathrm{w}$ metafizyce idealistycznej ontologię przyrody wyrażoną $\mathrm{w}$ filozofii pitagorejsko-platońskiej. W ostatnim ujęciu przyjmuje się istnienie świata niematerialnego. Ta ostatnia koncepcja przyrody, w przeciwieństwie do poprzednich, w których nie istnieje nic poza światem przyrody, jest więc naturalistyczna wyłącznie $\mathrm{w}$ tym sensie, że żaden nadnaturalny byt nie ingeruje w przyrodę.

Ostatnią starożytną i kluczową dla średniowiecznego naturalizmu byłaby ontologia hylemorfizmu arystotelesowskiego. Różnica między jego odmianą starożytną i średniowieczną polegałaby na tym, że w tej drugiej przyjmowano, iż przyroda ma swój początek w jakimś momencie przeszłości, wraz z jej porządkiem pochodzi od Stwórczego działania Boga, będącego bytem nadnaturalnym, transcendentnym wobec przyrody, oraz że Bóg ma i niekiedy wykorzystuje władzę wywoływania w przyrodzie skutków, wykraczających poza możliwości zawarte w naturach poszczególnych bytów stworzonych.

Arystoteles zgadzał się, że niekiedy przyroda działa w sposób „nienormalny", czyni to jednak jakby sama z siebie. Oprócz naturalnych niezwykłych zdarzeń przyrodniczych średniowieczna koncepcja przyrody dopuszczała także niezwykłe zdarzenia, będące wynikiem uległości przyrody wobec swojego Stwórcy wytwarzającego skutki wbrew znanej filozofom naturze stworzeń. 
Powstanie i rozwój nauki nowożytnej wprowadził na miejsce arystotelesowskiego hylemorfizmu atomistyczne rozumienie przyrody. Była to jednocześnie mechanistyczna i deterministyczna koncepcja przyrody. Z wyższego poziomu analizy czerpano założenia, według których materia jest czynnikiem biernym, co według niektórych miało prowadzić do odrzucenia poglądu o tajemniczym oddziaływaniu na siebie bytów niemających ze sobą bezpośredniego kontaktu. Stąd problem Newtona $\mathrm{z}$ wyjaśnieniem natury grawitacji w ujęciu mechanistycznym, jako że koncepcja oddziaływania grawitacyjnego bardzo przypominała ideę działania na odległość, z którą mechanika Newtona miała właśnie zrywać. W każdym razie nowa ontologia przyrody była atomistyczna, mechanistyczna i deterministyczna.

Wraz z rozwojem nauk przyrodniczych coraz silniej akcentowały swoją obecność także tendencje redukcjonistyczne, które ostatecznie wyrugowały z naukowego ujęcia przyrody ożywionej koncepcje witalistyczne, popularne jeszcze na przełomie XIX i XX wieku. W ramach ujęcia redukcjonistycznego przyjmuje się więc, że fundamentem wszystkich zjawisk fizycznych są obiekty i procesy badane przez fizykę cząstek elementarnych. Redukcjonizm w biologii zakłada możliwość wyjaśnienia funkcjonowania organizmów przez odwołanie do struktur i zjawisk badanych przez biologię molekularną. W naukach o świadomości przyjmuje się, że właściwym podejściem do badań jest analiza struktur i procesów zachodzących w mózgu. Ten redukcjonistyczno-mechanistyczny typ naturalizmu stanowi ontologiczną podstawę dominująca, ale nie jedyną w naukach przyrodniczych XX wieku.

Warto tu zwrócić uwagę, że protestancki teolog Richard Bultman, właśnie odwołując się do mechanicystycznego obrazu przyrody prezentowanego przez XIX-wieczną naukę, argumentował na rzecz możliwości jedynie egzystencjalistycznej interpretacji relacji Biblijnych o cudownych zdarzeniach zaburzających porządek przyrodniczy. Według Bultmana Bóg nie działa w obiektywnej sferze przyrody, a wspomniane opisy należy przeinterpretować na język doświadczenia osobowego, zastosować do nich interpretację egzystencjalistyczną. Na tym zasadza się jego koncepcja demitologizacji chrześcijaństwa. ${ }^{34}$ Skoro przyroda jest ściśle deterministycznym mechanizmem, to wszelkie przedstawienia obiek-

\footnotetext{
${ }^{34}$ Por. BArBour, Issues..., s. 431-434.
} 
tywnego działania Boga w świecie, zarówno Biblijne, jak i dawne teologiczne przedstawienia takiego działania, czy czasoprzestrzenne opisy relacji Boga, sfery nadnaturalej i świata są, według Bultmana, oparte na przestarzałym, fałszywym obrazie rzeczywistości. Bultman przyjmował, że od tego fałszywego obrazu uwalnia nas nauka pokazująca świat zgodny z ontologią mechanicyzmu Newtonowskiego, który w XIX wieku jawił się jako zasadniczo ostateczny, prawdziwy obraz przyrody.

Dziś różne gałęzie nauk przyrodniczych związane są jednak z alternatywną ontologią. Niektóre interpretacje zdarzeń opisywanych przez fizykę kwantową przyjmują ograniczenie determinizmu przyrodniczego, dostrzegając $\mathrm{w}$ opisywanych przez nią procesach pewną ontologiczną otwartość czy elastyczność. W tych interpretacjach nie traktuje się nieprzewidywalności zdarzeń kwantowych jako jedynie wyrazu niedoskonałości metod poznawczych. O indeterminizmie, ale już rozumianym jedynie jako nieprzewidywalność, mówi się w przypadku nieliniowych procesów dynamicznych, choć występują też nieliczni przedstawiciele stanowiska o rzeczywistej ontologicznej otwartości tych procesów. ${ }^{35}$ Niektóre koncepcje wolności w świecie, w tym wolnej woli człowieka, wiążą indeterminizm $\mathrm{z}$ wysokim stopniem złożoności oddziaływań, relacji i uwarunkowań, jakim podlega człowiek i w istocie sprowadzają wolność do nieprzewidywalności. $Z$ drugiej strony mamy też ujęcia antyredukcjonistyczne, także w analizach zjawisk poziomu atomowego, odwołujące się do koncepcji różnych poziomów złożoności, kategorii emergencji czy superweniencji.

Barbour krytykuje koncepcję Bultmana o niedziałaniu Boga w świecie przyrody, stwierdzając, że jego demitologizująca teologia opierała się na przestarzałym, XIX-wiecznym obrazie przyrody zdominowanym przez mechanicyzm deterministyczny. ${ }^{36}$ Barbour zakłada więc, że jeśli nauka utrzymywałaby mechanicystyczno-deterministyczne ujęcie, to rzeczywiście należałoby wykluczyć

${ }^{35},[. .$.$] nieprzewidywalność układów chaotycznych jest oznaką tego, iż ich zachowanie rze-$ czywiście charakteryzuje się pewnym stopniem ontologicznej otwartości” (John C. Polkinghorne, Poza nauką. Kontekst kulturowy wspólczesnej nauki, przeł. Danuta Czyżewska, Amber, Warszawa 1998, s. 77). Por. też John C. Polkinghorne, Exploring Reality. The Intertwining of Science and Religion, Yale University Press, New Haven and London 2005, s. 35; John C. PolkingHORNE, Belief in God in an Age of Science, Yale University Press, 1998, rozdz. 3; John C. PolKInghorne, Faith, Science and Understanding, Yale University Press 2000, s. 99-101 (cyt. za: POLKINGHORNe, Exploring Reality..., s. 35). 
koncepcję obiektywnego działania Boga w świecie przyrody. I w istocie Barbour przyjmuje pewne elementy Whiteheada filozofii procesu, bazującej na indeterministycznej interpretacji zjawisk kwantowych. Przyjęcie tej interpretacji pozwalać ma na uzasadnienie poglądu o niewykrywalnym dla nauki, a więc nie stojącym z nią w konflikcie, wpływie Boga na świat.

Pomijając analizę samej koncepcji Whiteheada, która w istocie sprowadza się głównie do twierdzeń z najwyższego metafizycznego poziomu analizy, można zauważyć, że wspólnym przekonaniem Bultmana, jak również Barboura i innych teistycznych naturalistów, jest stanowisko, że Bóg nie może robić rzeczy, które są sprzeczne z naukowym opisem świata, a dokładniej z ontologią przyrody przyjmowaną przez naukę. Sam Barbour, akcentując otwartość ontologiczną świata, wielopoziomowość rzeczywistości, współzależność między poziomami i bytami przyjmuje raczej, jak prezentowałem to wyżej, że Bóg działa w sposób zgodny z koncepcją stałego stworzenia bez ingerencji, a obecny naukowy opis funkcjonowania świata jest opisem tego Bożego działania.

Twierdzenie, że Bóg nie narusza naturalnego porządku uzasadniane jest między innymi koncepcją integralności natury Boga ${ }^{37}$ Interesujące jest to, że ta koncepcja Boga wywodzi się z teologii średniowiecznej, w której przyjmowano jednocześnie, że Bóg, bez naruszenia swojej natury, może działać w przyrodzie, wywołując w niej skutki, których sama przyroda wytworzyć nie jest w stanie.

Akceptacja interwencjonizmu przez teizm tradycyjny nie musiała być wynikiem luk w przyrodniczej wiedzy na temat poszczególnych procesów przyrodniczych. Hylemorfizm Arystotelesa, tak samo jak współczesna ontologia przyrody, pozwalał tłumaczyć wszystkie znane zjawiska i tak samo prowadził też do różnych problemów, czyli szczegółowych luk w opisie przyrody, co do których można było zakładać, że zostaną kiedyś w ramach nauki bazującej na tej ontologii wyjaśnione. Różnica między podejściami średniowiecznych filozofów przyrody i współczesnych teistów naturalistycznych polega na tym, że ci pierwsi

\footnotetext{
${ }^{36}$ Por. BARBour, Issues..., s. 434.

${ }^{37}$ „Rozumny Bóg musi szanować reguły rozumu. [...] Nie może być kimś, kto arbitralnie interweniuje w zachodzące $\mathrm{w}$ nim [w świecie - PB] procesy, a same te procesy powinna cechować spójność stanowiąca odbicie istoty Boga. W tej perspektywie, prawa natury okazują się znakami Bożej wierności” (Polkinghorne, Nauka i stworzenie..., s. 101).
} 
przyjmowali, że niektóre $\mathrm{z}$ tych luk w opisie zdarzeń przyrodniczych da się i należy wyjaśniać wyłącznie przez odwołania do działania czynników nadnaturalnych. Teistyczni naturaliści przyjmują, że nie istnieją luki w naturalistycznym opisie zdarzeń zachodzących w sferze empiryczno-przyrodniczej.

Stanowisko teizmu tradycyjnego wynikało z przyjęcia filozoficznych założeń teizmu o relacji przyrody i świata nadnaturalnego, głoszących możliwość interwencji nadnaturalnych $\mathrm{w}$ przyrodzie. Na podstawie tego założenia szereg zdarzeń rozumiano jako wynik właśnie takich interwencji. Teizm naturalistyczny przyjmuje filozoficzne założenie z poziomu ontologii przyrody, że w naturę nic z zewnątrz nie ingeruje. Czy założenie to wymuszone zostało rozwojem nauki? Hylemorfizm Arystotelesa był tak samo naturalistyczny jak koncepcja, że wszystkie zdarzenia $\mathrm{w}$ świecie są wynikiem działania sił przyrodniczych funkcjonujących zgodnie z regularnościami ujawnianymi przez naukę współczesną. Hylemorficzna ontologia jest tak samo naturalistyczna, to znaczy niewymagająca zewnętrznych interwencji, jak atomistyczna, mechanistyczna, deterministyczna czy indeterministyczna, redukcjonistyczna czy odwołująca się do poziomów złożoności ontologia przyrody wykorzystywana w nauce współczesnej. Elementem żadnego $\mathrm{z}$ tych dwóch odmian ontologii nie jest odwołanie do specjalnych interwencji zaburzających naturalny porządek. Teistów naturalistycznych różni od tradycyjnych uznanie, że przyjmując naturalistyczną ontologię przyrody, zakładaną przez współczesną naukę, można wyjaśnić wszelkie zdarzenia zachodzące w świecie czy szczegółowe własności przyrody. Mamy tu więc do czynienia z przesunięciem autorytetu poznawczego na poziomie analizy odpowiadającym ontologii przyrody. Polega ono na odejściu od przyjmowanych na tym poziomie założeń tradycyjnego teizmu na rzecz ontologii przyjmującej samowystarczalność przyrody w wytwarzaniu wszystkich szczegółowych zdarzeń i własności, które są opisywane na najniższym, empirycznym poziomie analizy.

Piotr Bylica 


\title{
The Sketch of the Model of Levels of Analysis in the Studies of Relation Between Science and Religion
}

\begin{abstract}
Summary
I propose the model of division of statements on the reality that differentiate them according to the degree of their empirical character. The following model is supposed to facilitate analysis of propositions on the relation of science and religion. One extreme are metaphysical statements (in the logical empiricism's view of metaphysics) that are empirically neutral. The other extreme are empirical statements characterized by the maximum level of testability. It is demonstrated how ignoring the levels of analysis influences some positions on science and religion.

Problematic positions are named "too easily conflicting" and "too easily reconciliating" science and religion. In the first case I present negative reception of scientific theory of evolution by Michał Chaberek on the basis of ontological assumptions that are in conflict with assumptions of this theory. The problem of "too easy reconciliation" of science and religion is the shift in the meaning of categories from the one on the lowest, empirical level, toward the meaning that belongs to the highest, metaphysical level of analysis. This problem is illustrated by the shift from interventionist concept of creation and divine action in the world toward its non-interventionist interpretation that limits God's actions only to sustaining the world in its existence. We can find this shift in some theistic naturalism positions.

In the last part I argue that the main difference between the medieval (traditional) and the contemporary positions on natural philosophy and religion that attempt to accommodate Christian and scientific worldviews is that contemporary thinkers ascribe epistemic authority not only to empirical statements of contemporary science, but also to its philosophical naturalistic assumption from higher levels of analysis. Holding these anti-interventionist and monistic ontology of nature leads them to extremely non-empirical understanding of relation between the supernatural and the natural world.
\end{abstract}

Keywords: levels of analysis, science and religion, Christian theism, naturalism, interventionism, God of the gaps, theistic naturalism.

Słowa kluczowe: poziomy analizy, nauka a religia, teizm chrześcijański, naturalizm, interwencjonizm, Bóg luk, teistyczny naturalizm. 